\title{
Transfer and Transcriptional Expression of Coleopteran cryIIIB Endotoxin Gene of Bacillus thuringiensis in Eggplant
}

\author{
Qi Chen, Gojko Jelenkovic', Chee-Kok Chin, Sharon Billings, Jodi Eherhardt, \\ and Joseph C. Goffreda \\ Department of Plant Science, Cook College, New Jersey Agricultural Experiment Station, Rutgers \\ University, The State University of New Jersey, New Brunswick, NJ 08903 \\ Peter Day \\ The Center for Molecular Biology in Agriculture, Cook College, New Jersey Agricultural Experiment \\ Station, Rutgers University, The State University of New Jersey, New Brunswick, NJ 08903 \\ Additional index words. Bt, Colorado potato beetle, Leptinotarsa decemlineata, gene and protein expression, insect resistance
}

\begin{abstract}
Three constructs of a coleopteran toxic cryIIIB B acillus thuringiensis gene were engineered and incorporated into eggplant (Solanum melongena L.). Southern blot analysis of the eight primary transformants and segregational analysis of their $\mathbf{R}$, progenies indicated that the chimeric cryIIIB constructs in each of the transgenic plants were stably incorporated at a single locus or at multiple sites within the same linkage group and that they were regularly transmissible to the progeny. The results of Northern blot and RNase protection analyses demonstrated that transcription of the cryllIB mRNA takes place in plant cells, but only a small amount of the expected entire length transcripts were produced. The amount of the 5' end mRNA fragment produced was at least 30 to 40 times more abundant than the amount of the 3' end mRNA fragment. This could be interpreted to mean that either the two ends of the mRNA are of different stability or that the transcription process is often interrupted and only a few mRNAs complete the entire process to the end. When the transgenic plant mRNA was reverse-transcribed, amplified by polymerase chain reaction, and hybridized to the cryIIIB probe, two smaller molecular weight mRNA species were identified. Thus, the preponderance of the crylIIB mRNA in transgenic plants exists as a truncated species, a situation similar to that of cryI genes when expressed in transgenic plants. Seedlings from the eight independent transgenic plants were tested for Coleopteran insect resistance. However, they did not demonstrate any significant resistance to the first and second instar larvae of the Colorado potato beetle (Leptinotarsa decemlineata Say).
\end{abstract}

The insecticidal crystal protein genes of Bacillus thuringiensis (Bt) have emerged as an important gene family in the biotechnological manipulation of insect resistance in cultivated plant species (McGaughey and Whalon, 1992). In their native host, these genes are expressed during bacterial sporulation, producing proteins in the form of crystals. Upon ingestion of the spores, the toxic protein crystals are solubilized and processed in the midgut of an insect larva, causing poretion in the membrane of the epithelium cells and subsequently leading to mortality of the larva (English and Slatin, 1992). The crystals and spores, in various formulations and under various trade names, have been successfully used during the last 2 decades in controlling some important agricultural pests (Aronson et al., 1986). The main problem with such an approach is the high cost of the spore and crystal production and the relatively fast degradation of the toxic proteins under normal conditions of plant growth and development (Dulmage, 1980).

Received for publication 17 Oct. 1994. Accepted for publication 11 May 1995. New Jersey Agricultural Experiment Station Journal Series paper no. This research was supported by state and Hatch funds. We acknowledge the New Jersey Commission on Science and Technology for financial support, Joe Patt and James Lashomb (Cook College) provided valuable assistance in the insect bioassays. Daniel Palmer of the Beneficial Insect Rearing Laboratory, New Jersey Dept. of Agriculture, supplied us with Colorado potato beetle eggs. We thank the Ecogen Co. for supplying us with the cryllIB gene and W.P. Donovan for his advice in the protein work. We are grateful to Smith-Kline Beecham Pharmaceuticals for supplying us with lithium chloride, which is an essential ingredient of Augmentin. The cost of publishing this paper was defrayed in part by the payment of page charges. Under postalregulations, this paper therefore must be hereby marked advertisement solely to indicate this fact.

${ }^{1}$ To whom reprint requests should be addressed.
With the advent of a biotechnological approach to genetic plant manipulation, it has become possible to transfer and integrate $B t$ crystal protein genes into plant genomes and obtain a genotype resistant to a particular insect pest (Boulter et al., 1990; Brunke and Meeusen, 1991). The notable feature of these genes is that their toxic products are highly specific to a particular taxonomic group of insects. The genes are classified into four major groups according to their toxic specificity: cryI, cryII, cryIII, and cryIV, which are toxic to lepidopteran, both lepidopteran and dipteran, coleopteran, and dipteran insects, respectively (Hofte and Whiteley, 1989). A new group, cryVI, has been described recently, the products of which are active against nematodes (Feitelson et al., 1992). In addition to the specificity of their products, the genes in the same major group display considerable structural polymorphism, which is a basis for further subgrouping (Hofte and Whiteley, 1989). There are $60 \mathrm{Bt}$ crystal protein genes characterized at the nucleotide level (Adang et al., 1993). CryIA(a), cryIA(b), and cryIA $(c)$ have been introduced into tobacco (Adang et al., 1985; Barton et al., 1987; Murray et al., 1991; Perlak et al., 1990; Vaeck et al., 1987); cryIA(b) and cryIA(c) into tomato (Fischhoff et al., 1987; Perlak et al., 1990) and cotton (Perlak et al., 1990); cryIA(b) into corn (Koziel et al., 1993); cryIA(c) into potato (Cheng et al., 1992); and cryIA(a) into cranberry (Serres et al., 1992) and poplar (McCown et al., 1991). These 'are all genes of the lepidopteran group. When cryI genes with intact coding sequences were placed under various regulatory sequences for expression in plant cells, no detectable expression of the genes was determined (Vaeck et al. 1987). However, the chimeric constructs with truncated 3 ' termini of the coding region showed a low level of expression at the mRNA 
and toxicity level (Barton et al., 1987; Vaeck et al., 1987). In contrast, a relatively high level of expression of the truncated cryIA(b) gene has been reported in transgenic tobacco grown under greenhouse and field conditions (Carozzi et al., 1992). To enhance the level of expression of $\operatorname{cryIA}(b)$ at the protein level, Perlak et al. (1991) changed the nucleotide at the third position in certain codons of the truncated coding region so that the AT to GC ratio was altered. They observed a $>100$-fold increase in the protein expression in transgenic tomato plants. Since the resultant amino acid sequence was almost identical to the wild type gene, it was concluded that bias in codon usage is one of the main reasons for cryI gene low expressivity in transgenic plants (Perlak et al., 1991). More drastic alterations of the codons of the same gene $[$ cryIA $(b)]$ dramatically increased its expression at the protein level in transgenic maize (Koziel et al., 1993).

At least five of the cryIII (coleopteran-specific) genes have been sequenced: cryIIIA (Hemstadt et al., 1987), cryIIIB (Donovan et al., 1988; Sick et al., 1989), cryIIIB2 (Donovan et al., 1992), cryIIIC (Peferoen et al., 1990), and cryIIID (Lambert et al., 1992). Only a few studies have been carried out on the expression of the cryIII family of genes in transgenic plants. Murray et al. (1991) reported poor transient expression of the native cryIIIA gene at the mRNA level in electroporated carrot. protoplasts, and similar results were reported by Adang et al. (1985) using the same gene. When the native gene was modified for optimal expression in plant cells, the level of expression was dramatically increased and resistance of transgenic potato plants to the Colorado potato beetle (CPB) was observed (Adang et al., 1993). In a similar experiment, CryIIIA protein accumulated to $0.5 \%$ to $1.0 \%$ of the total when a synthetic cryIIIA gene was introduced into tobacco plants (Sutton et al., 1992), while only $0.001 \%$ to $0.02 \%$ CryIIIA protein was detected when the native gene was used (Barton et al., 1987; Vaeck et al., 1987).

Here we report on making cryIIIB chimeric constructs, incorporating them into eggplant genomes, and their expression at the RNA level in transgenic plants. Specifically, we were trying to incorporate the coleopteran-type cryIIIB gene and produce eggplant genotypes resistant to CPB. Such genotypes would be used for commercial planting or as breeding stock in eggplant breeding programs.

\section{M aterials and Methods}

Engineering the chimeric cryIIIB constructs. A gene coding for the coleopteran insecticidal protein (cryIIIB) was made available to us by Ecogen Inc. The coding region of the insecticidal protein was delineated to the nucleotide positions $655\left(5^{\prime}\right)$ and 2690 (3') of this gene. To express this gene in plants, the regulatory sequences controlling its expression in bacteria were deleted and replaced by those that were expected to regulate its expression in plant cells. Using the double stranded Nested Deletion Kit (Pharmacia,

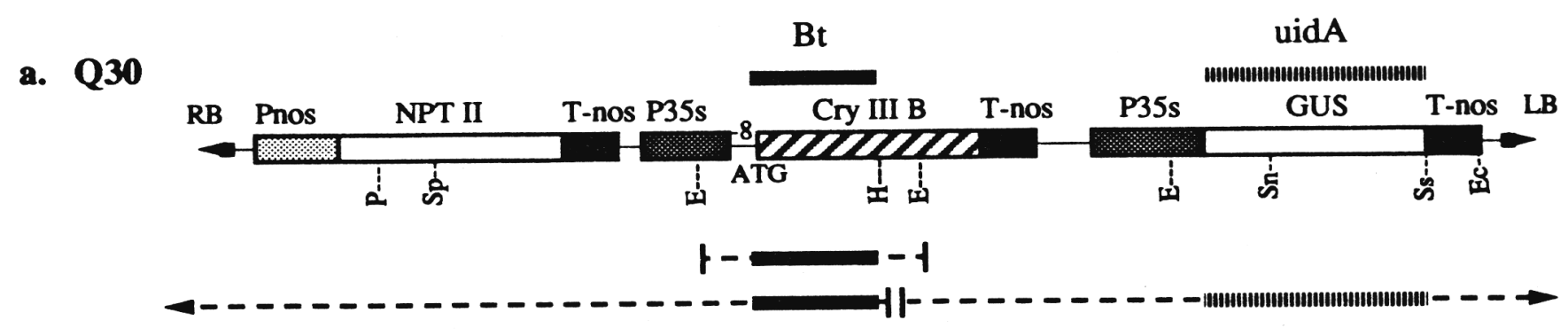

b. $\mathbf{Q 4 0}$
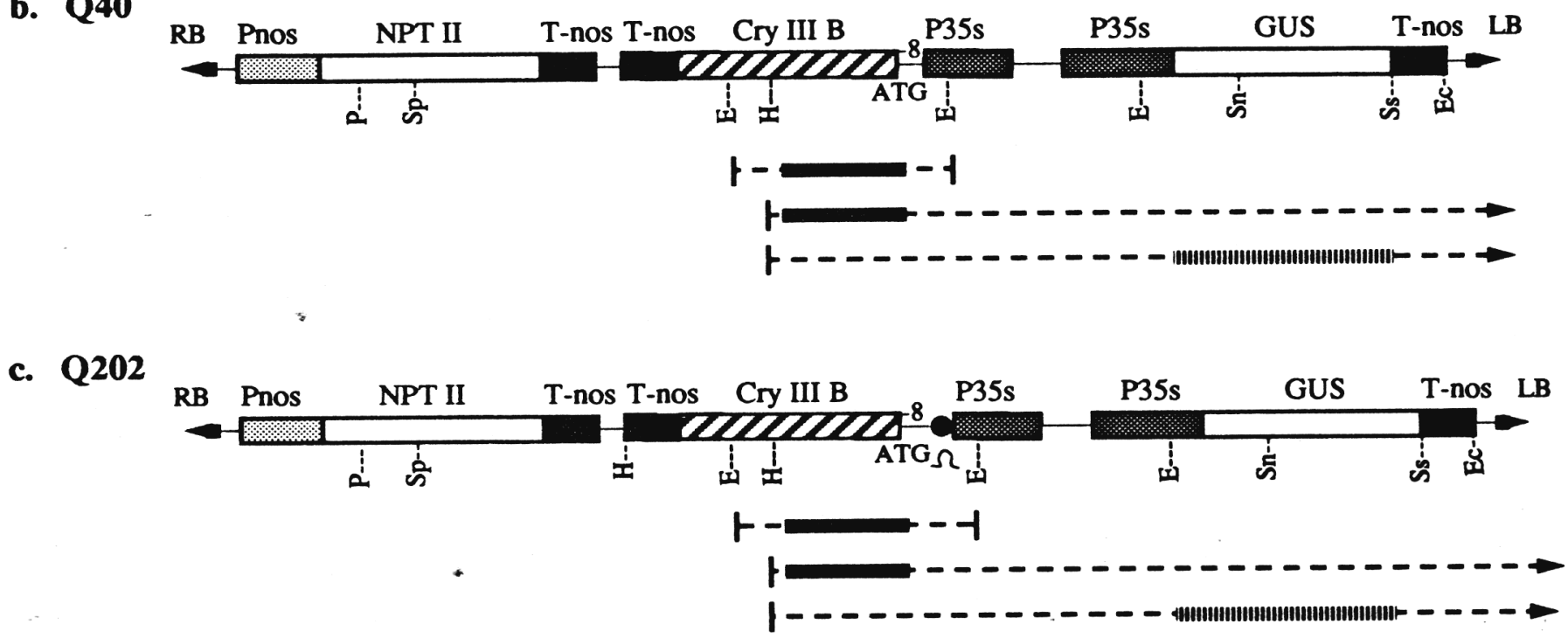

Fig. 1. Structural parameters of the three cryIIIB constructs [(a) 430; (b) Q40; (c) Q202] along with the expected fragments in southern analysis of transgenic eggplants when two probes are used (cryIIIB and uidA). Below each construct, a diagram of the expected fragment is shown depicting length and homologous sequences expected after hybridization with the probes. Homologous region plus dashed line $=$ the expected size of a fragment. The restriction enzyme sites are as follows: $E=E c o R V, E C=E c o R I, H=H i n d I I I, P=P s t I, S n=S n a I, S p=S p h I$, Ss $=$ Sst $I$. The prefix $\mathrm{P}=$ the promoter regions and the prefix T $=$ the terminator regions. 
Piscataway, N.J.), a series of deletions at the 5 ' terminus were generated, differing in sequence length before the ATG start codon. These truncated forms of the $c r y I I I B$ gene were further modified by removing a 166-bp fragment by restriction with Ssp I at the 2724 nucleotide position at the 3 ' terminus. The truncated gene containing a 150-bp leader sequence was cloned into plasmid pCaMVCN (Pharmacia) containing the cauliflower mosaic virus (CaMV) 35S promoter and nopaline synthase terminator (NOST), with a deleted CAT gene. An 8-bp leader of cryIIIB was also cloned into plasmid pMJD36 containing the 35S promoter and omega translation enhancer (Gallie et al., 1987). The NOS-T was inserted as a separate fragment at the 3 ' end of the cryIIIB gene. Both constructs were restricted from the cloning vectors and ligated into the pBI121 plasmid (Clontech, Palo Alto, Calif.) at the unique Hind III polylinker site, using blunt-end ligation, between the NPTII and GUS (uidA) reporter genes, in parallel and antiparallel direction, producing four constructs (Q30, Q40, Q201, and 4202). The pBI121 plasmid was then transferred into Agrobacterium tumefuciens strain LBA4404 using a direct DNA transfer system (Gynheung et al., 1988) for use in plant transformation studies. Only three (Q30, Q40, and Q202) of the four constructs were successfully used in these plant transformation studies (Fig. 1).

Transformation, regeneration, andselection. 'Black Jack' eggplant seeds were surface-sterilized twice: first, with $20 \%$ Clorox followed by five rinses and an overnight soak in a thin film of water, then after $24 \mathrm{~h}$, with $10 \%$ Clorox followed by three rinses. This double sterilization effectively eliminated contamination caused by fungal spores that germinated in the overnight soak. Seeds wereplaced in test tubes on $10 \mathrm{~m} 1$ of half-strength Murashige and Skoog (MS) medium (Murashige and Skoog, 1962) containing $3 \%$ sucrose, $0.6 \%$ agar, and no plant growth regulators. The tubes were maintained at $26 \mathrm{C}$ and a $16-\mathrm{h}$ photoperiod at $50 \mu \mathrm{mol} \cdot \mathrm{m}^{-2} \cdot \mathrm{s}^{-1}$. When the seedlings had reached an average height of $4 \mathrm{~cm}, 15$ to 18 days after germination, and before the formation of primary leaves, the seedlings were decapitated by a transverse cut through the stem below the cotyledons. The cut surface of each hypocotyl was inoculated with an Agrobacterium tumefaciens culture, either as liquid or paste. After a cocultivation time of $24 \mathrm{~h}$, the antibiotic augmentin $\left(125 \mu \mathrm{g} \cdot \mathrm{ml}^{-1}\right)$ (Smith-Kline Beecham Pharmaceuticals, Philadelphia) was added to suppress bacterial growth. Multiple shoots regenerated from the cut surface within 2 weeks. After about 6 weeks, when the regenerating shoots had developed two to three leaves, tissue samples from an apical leaf were harvested and tested for the presence of $\beta$ - glucuronidase (GUS) activity (Jefferson, 1987). The shoots wereexcised and placed in MS medium containing Augmentin $\left(300 \mu \mathrm{g} \cdot \mathrm{ml}^{-1}\right)$ for rooting. Once rooted, the plants were transferred to the greenhouse. We described details of eggplant transformation procedures elsewhere (unpublished data).

Seeds obtained by selfing the primary transformants $(\mathrm{R}$,) were germinated and the progeny produced $(\mathrm{R}$,$) were tested for expres-$ sion of the GUS reporter gene.
Southern blot analysis. Genomic DNA of eggplant was isolated from young leaf tissue using the Junghans and Matzlaff (1990) procedure. Five to ten micrograms of DNA was restricted with either Eco RV or Hind III and run on a $0.9 \%$ agarose gel. The DNA was blotted onto a nylon (Nytran) membrane according to Maniatis (1989). Two different DNA probes were used in filter hybridization: a) a $1.2-\mathrm{Kb}$ cryIIIB fragment from the 5 ' end to the Hind III site; $b)$ the entire $1.8-\mathrm{Kb}$ coding sequence of the GUS reporter gene restricted from pBI221 (Clontech) with Sst I and Xba I. The probes were labeled with the oligo labeling kit (Pharmacia) and hybridization was done using $2 \times 10^{6} \mathrm{cpm} / \mathrm{ml}$ of the $\mathrm{P}^{32}$-dCTP probe. Hybridization, washing, and autoradiogram development was done as described by Maniatis (1989).

Northern blot analysis. Total RNA was isolated from young leaves of eggplant using the method of DeVries et al. (1988). Poly $(\mathrm{A})^{+}$mRNA was separated from total RNA with an oligo (dt) cellulose column according to a method described by Kingston (1989). From 3 to $19 \mu \mathrm{g}$ of mRNA was electrophoresed on a denaturing gel and transferred to a nylon membrane (Gene Screen; DuPont, Boston). Hybridization was carried out according to methods described by Selden (1989).

RNase protection assays. RNA probes for RNase protection assays were transcribed and labeled in vitro with ${ }^{32} \mathrm{P}$-CTP using a kit (Riboprobe Gemini II; Promega, Madison, Wis.). Two DNA fragments were used as templates for this in vitro transcription. They were obtained in the following way. Plasmid pGE34, a recombinant of pGEM 32 and the cryIIIB gene, was restricted with Eco $R V$ and $P v u I I$, which produced a fragment containing $376 \mathrm{bp}$ of the most distal portion of the cryIIIB gene attached to the Sp6 promoter (Fig. 2). This fragment was transcribed to produce a riboprobe for the 3' terminus of the cryIIIB mRNA. For the riboprobe of the $5^{\prime}$ terminus, the pGE34 plasmid was restricted with $P$ st $I$, thus deleting a large Pst I fragment and producing a new plasmid, pGE34/PstI. This plasmid was restricted with Eco RI and $P v u I I$, and the resulting 137-bp fragment was used for transcription of the 5 ' probe. RNase protection experiments were performed on transgenic plants using a ribonuclease protection assay kit (RPA II; Ambion, Austin, Texas).

In vitro reverse transcription and $c D N A$ amplification with polymerase chain reaction $(P C R)$. One microgramof mRNA from transgenic eggplant specimen 430-2 and $1 \mu \mathrm{g}$ from a control were reverse-transcribed into the first cDNA strand using a 3' system kit (RACE; GIBCO-BRL, Gaithersburg, Md.) and further amplified by Taq DNA polymerase using PCR. The PCR amplification conditions were 94C for $1 \mathrm{~min}$ and $45 \mathrm{C}$ for 2 min for 35 cycles. An oligo dT (17-mer) and a 26-mer oligonucleotide derived from the cryIIIB gene fragment, including the translation initiation ATG codon, were used as primers in first-strand cDNA synthesis. The amplified cDNA was electrophoresed on a gel, transferred to a nylon membrane, and hybridized with the cryIIIB probe as described above.

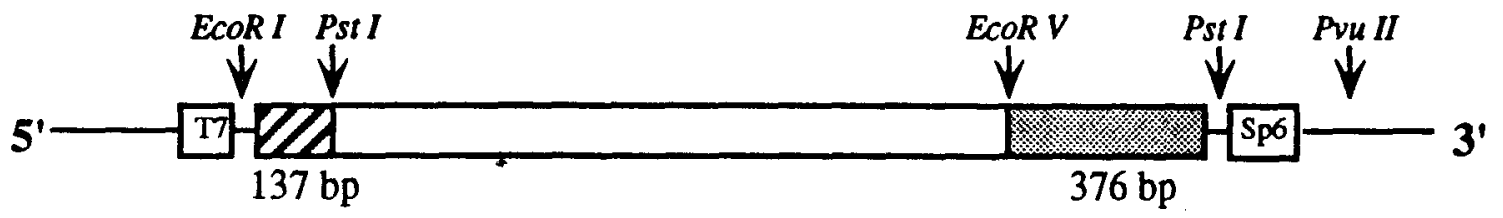

\section{CryllIB $\quad(2.0 \mathrm{~kb})$}

Fig. 2. Plasmid pGE34, containing the cryIIIB gene, from which 5' and 3' riboprobes were derived for RNase protection assays. Striped and shaded areas represents the 5 ' and 3' ends of cryIIIB, respectivley, and were used as riboprobes in RNase protection assays. 
Insect toxicity assays. Leaf petioles of the primary transgenic eggplants were inserted into wet oasis medium to preserve leaf turgidity, then placed in petri dishes. Two first- or second-instar larvae were placed in each petri dish on the leaves. The amount of leaf tissue consumed by the larvae and the rate of insect development were observed and compared with insects on control ('Black Jack') leaves. Five leaves from each genotype were tested per experiment and the experiments were repeated three times. In addition, control seedlings ('Black Jack') and about 400 R, seedlings, including GUS-positive and GUS-negative segregants from all original transformants, were individually caged and inoculated with first instar larvae in the growth chamber when the plants had six primary leaves. They were rated for resistance as described

\section{Results}

GUS assays of eggplant transformants and their derivatives. Eight transgenic eggplants produced with the seedling decapitation method were identified with the GUS assay, representing three of the constructs. This transformation method was used because of the high rate of shoot regeneration $(100 \%)$ in initial experiments. However, due to an extremely low frequency of transformants $(<0.1 \%)$, this approach has been replaced by using leaf explant tissue with selectable medium (unpublished data). The transformed plants were successively numbered according to the original A. tumefaciens strains used (Fig. 1). The transformants appeared normal in phenotype and growth habit, and they reached the reproductive phase showing no visible abnormality in fruit and seed set in the greenhouse.

Stability and transmissibility of the transferred constructs. The pattern of segregation for GUS activity in most of the $\mathrm{R}_{1}$ progenies indicate that, in each independent transformant, the integration of the cryIIIB constructs appears to be confined to a single locus in the genome (Table 1). Segregation in Q40-1 progen is different in that most $\mathrm{R}$, seedlings were of a negative phenotype (Table 1). Segregants of Q30-1 demonstrated a preponderance of GUS-negative plants. We cannot offer a definite interpretation of this data at this time.

Southern blot analysis. Southern blot analysis was used to ascertain the physical integration of the cryIIIB constructs and their organization in the chromosomes of the transgenic genotypes. When plant DNA was restricted with Eco $R V$, the cryIIIB probe was expected to hybridize to the fragment between the $E c o$ $R V$ sites in the truncated $c r y I I I B$ gene and its $35 \mathrm{~S}$ promoter and to produce a single band of about $2.0 \mathrm{~Kb}$ on the autoradiograph Indeed, this band was observed in all GUS-positive genotypes (Figs. 1 and 3a). Two additional bands (not shown) were observed for the Q40- 1 specimen.

Table $1 . R_{1}$ progenies of transgenic eggplants tested for 3: 1 segregation ratios (presence vs. absence of GUS activity).

\begin{tabular}{lcccc}
\hline \hline $\begin{array}{l}\mathrm{R}_{0} \\
\text { genotype }\end{array}$ & $\begin{array}{c}\text { Positive } \\
\text { (no.) }\end{array}$ & $\begin{array}{c}\text { Negative } \\
\text { (no.) }\end{array}$ & $x$ square & $\mathbf{P}$ \\
\hline $430-1$ & 30 & 19 & 4.96 & $0.05-0.02$ \\
$430-2$ & 26 & 12 & 0.88 & $0.50-0.30$ \\
Q30-3 & 35 & 12 & 0.01 & $0.95-0.90$ \\
Q30-4 & 39 & 11 & 0.24 & $0.70-0.50$ \\
Q30-5 & 35 & 10 & 0.19 & $0.70-0.50$ \\
Q30-6 & 36 & 9 & 0.60 & $0.50-0.30$ \\
Q40-1 & 7 & 43 & 99.22 & $<0.01$ \\
Q202-1 & 46 & 9 & 2.19 & $0.20-0.10$ \\
\hline
\end{tabular}

Since there is only one Hind III restriction site in the constructs, located in the middle of the cryIIIB gene, digestion of the DNA from transformed eggplant genotypes with Hind III would produce two large fragments, carrying the left and right borders of T-DNA (defined as the left and right fragments, respectively), the size depending on the positions. of the nearest Hind III sites in the transgenic plant genome. Since the cryIIIB probe consisted of the 5' Hind III segment of the construct, hybridization with the plant DNA should produce one band with one insertion and more than one band, if more insertions are present. Therefore, the Hind III bands would differ in number, size, and intensity, depending on the number and place of insertion (Fig. 1). Four of the six analyzed genotypes of the Q30 series displayed a single band between 7 and
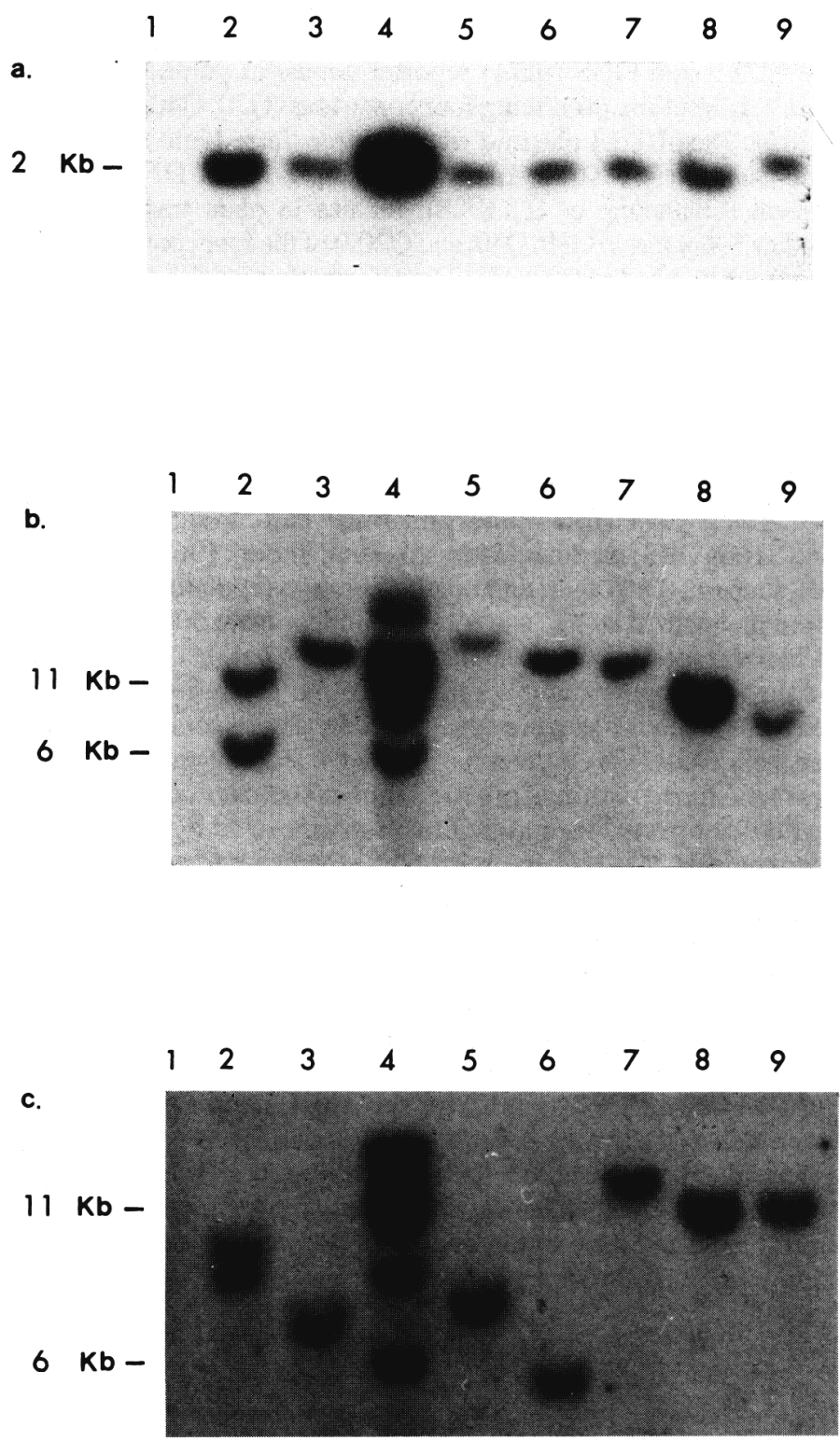

Fig. 3. Southern blot analysis of transgenic eggplant. (a) DNA restricted with Eco $R V$ and hybridized with the cryIIIB probe displayed expected bands of about $2 \mathrm{~Kb}$. (b) DNA restricted with Hind III and hybridized with the cryIIIB probe, displayed various sized bands depending on the Hind III site in the plant genome outside of the T-DNA site. (c) DNA restricted with Hind III and hybridized with the GUS probe displayed bands similar in numbers but not patterns to b. Order of samples for all figures is 1) control, nontransgenic sample, 2) 30-1, 3) 30-2, 4) 30-3, 5) 304, 6) 30-5.7) 30-6, 8) 40-1, 9) 202-1. 
$10 \mathrm{~Kb}$. The genotype Q30-3 displayed six bands indicating multiple cryIIIB inserts. A similar interpretation is offered for Q30-1, which displayed two bands (Fig. 3b). The GUS probe was expected to hybridize to the left fragment of the Hind III restricted DNA of the transgenic plants. In the case of Q40 and Q202, the produced bands should be the same size as the ones produced with the cryIIIB probe (Figs. $1 \mathrm{~b}$ and $\mathrm{c}$ and $3 \mathrm{c}$ ). Conversely, with the Q30 series, the two bands were of different sizes (Figs. la and 3c).

RNA expression of the coleopteran cryIIIB gene. In Northern blot assays, the genotypes Q30-1, Q30-2, Q30-4, and Q40-1 displayed weak signals at 1.2 to $1.4 \mathrm{~Kb}$ (Fig. 4a), while the remaining transgenic plants, along with the control, showed no hybridization signals. In the RNase protection experiments, hybridization with an antisense RNA fragment at the 5' terminus produced a major band of about $150 \mathrm{bp}$ in all tested genotypes except for the control (Fig. 4b). The intensity of the displayed signals was noticeably higher in four of the genotypes, with the weakest from Q30-3. In contrast, hybridization with an antisense
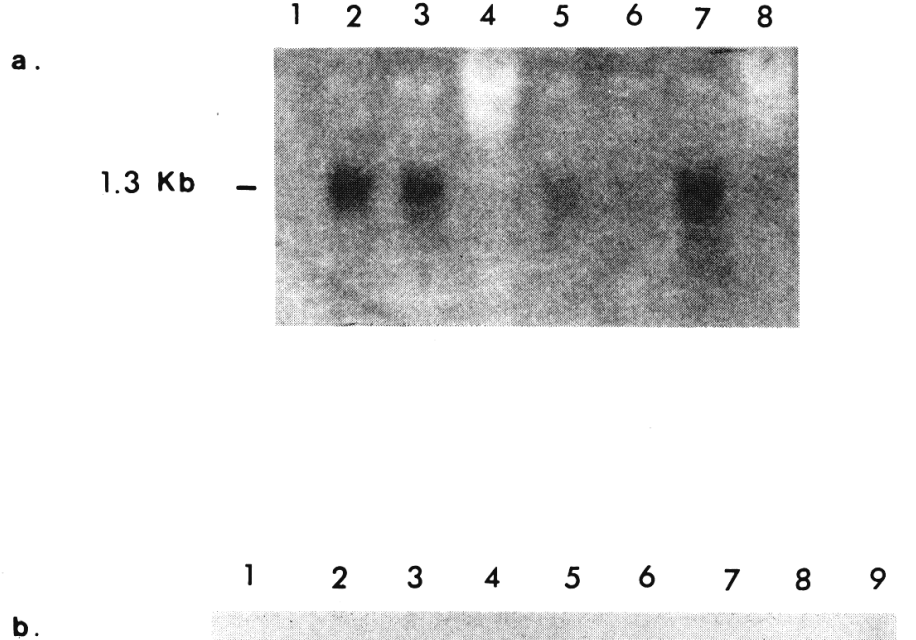

150
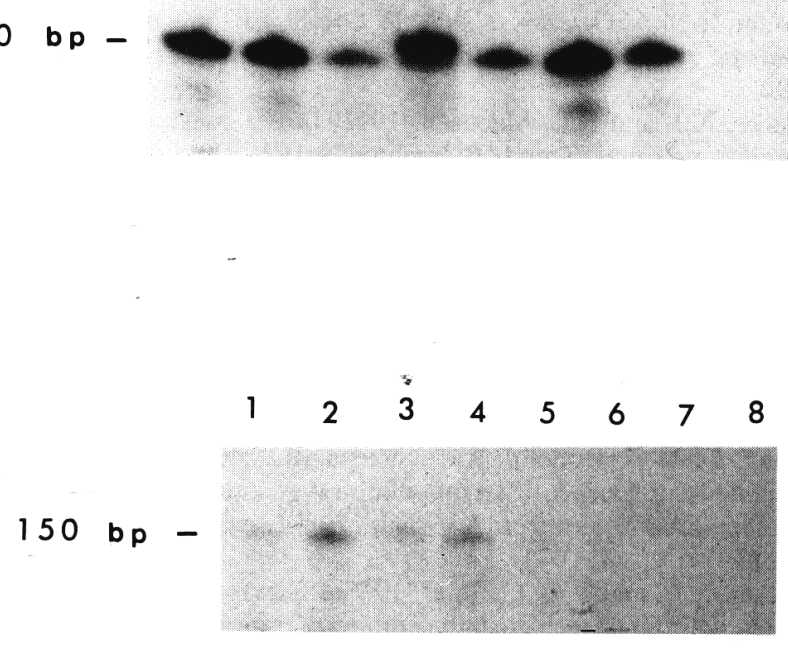

c.

Fig. 4. RNA analysis of transgenic eggplant. (a) Northern blot of mRNA hybridized with the $c r y I I I B$ probe, displayed 1.2 - to $1.4-\mathrm{Kb}$ fragment. Order of samples is 1 ) control, non transgenic sample 2) 30-1, 3) 30-2, 4) 30-3, 5) 30-4, 6) 30-6, 7) 40$1,8)$ 202-1. (b) RNase protection of mRNA hybridized with an antisense RNA 5 ' terminus probe. Order of samples is 1) 30-1, 2) 30-2, 3) 30-3, 4) 30-4, 5) 30$6,6)$ 40-1, 7) 202-1, 8) control, nontransgenic sample, 9) actin gene. (c) RNase protection of mRNA hybridized with an antisense RNA 3' terminus probe. Order of samples is 1) 30-1, 2) 30-2, 3) 30-3, 4) 30-4, 5) 30-6, 6) 40-1, 7) 202-1, 8) control, nontransgenic sample.
Fig. 5. Southern blot of eggplant cDNA of Q30-2 and control specimen produced from mRNA in vitroo transcription with $3^{\prime}$ RACE kit and amplification with polymerase chain reaction. Probe used was cryIIIB Hind III fragment DNA. Order of samples: 1) 30-2,

2) control, nontransgenic sample.

RNA fragment at the 3 ' terminus revealed signals in only five of the tested genotypes; these signals were conspicuously lower in intensity compared to those from the 5' terminus (Fig. 4c). The position of this band corresponds to the expected fragment of about $300 \mathrm{bp}$.

The cDNA amplified from the mRNA reverse transcripts of the transgenic 430-2 also hybridized-with the cryIIIB gene fragment probe that was used in our Southern and Northern hybridization experiments. Two distinct bands, corresponding to fragments of about $1.2 \mathrm{~Kb}$ and $0.6 \mathrm{~Kb}$ respectively, were present on the autoradiograph, whereas the control mRNA-amplified DNA did not show any bands. These results demonstrate that transcription of cryIIIB mRNA takes place in the transgenic eggplants. However, a band of the expected transcript size of $1.8 \mathrm{~Kb}$ is not observed on this autoradiograph; rather, two smaller molecular species whose origin is unknown at this time were observed (Fig. 5). Further studies on the stability of the cryIIIB mRNA are needed to understand the origin of the smaller molecular species in the transgenic plants.

Insect bioassay. Insect bioassays on $\mathrm{R}_{0}$, leaves in petri dishes or whole $\mathrm{R}$, plants under growth-chamber conditions demonstrated no noticeable difference in the quantity of consumed leaf areas between various transgenic and control eggplants. Likewise, the feeding pattern of the larvae on transgenic plants appeared to be the same as on control plants. Once initiated by a larva at a given spot, feeding continued at the same place, producing a large hole in the leaf, sometimes encompassing $30 \%$ of the entire leaf area. Four to five days after the insect inoculations, the leaves of plants were severely damaged in both types of assays, and the whole plants were almost completely defoliated after 8 to 10 days. The larvae continued their feeding on the main stem of the plants. Parallel with such voracious consumptions of leaf tissue, the larvae seemed to proceed with their normal growth and development, with no observable differences in the mortality between those feeding on the leaves of transgenic plants and those feeding on the control plants. These observations indicate, rather convincingly, that the consumption of the leaf tissue of transgenic eggplant is not inhibitory to the growth and development of CPB larvae.

\section{Discussion}

The evidence obtained by Southern analysis of the transgenic eggplants indicate that each of the tested genotypes is distinguishable by a unique banding profile on the autoradiograms, confirming their derivation from independent transformation events. Furthermore, this analysis shows that most (five) of the transgenic eggplants most likely contain a single copy of the cryIIIB construct. This agrees with previous reports showing that single-copy inserts are prevalent among transgenic genotypes (Budar et al., 
1986; Deroles and Gardner, 1988a; Heberle-Bors et al., 1988). The genotypes Q30-1 and Q30-3 contain more than one construct insertion, the former with at least two copies of the construct and the latter with five to six copies. Multiple-copy genotypes could result from multiple insertions at different loci along the chromosomes or at the same locus. The origin of multiplicity at a single locus remains unknown, although copy organization is either in tandem or as inverted repeats at a given locus (Deroles and Gardner, 1988b; Jones et al., 1987; Jorgensen et al., 1987). The interesting feature of Q30-3 is the variability in the size of the restricted fragments and their variability in signal intensity. This would suggest that there has been some rearrangement or scrambling of the involved constructs or that they are organized in a cluster with chromosomal DNA dispersed between the constructs. Segregational analysis of the R, progenies, showing a Mendelian pattern for the GUS (uidA) gene, provides further evidence that integration of the cryIIIB constructs in all transgenic eggplants (except Q40-1) is confined to a single locus or to multiple sites within the same linkage group. Also, it has been demonstrated that the chimeric constructs are stably incorporated into eggplant genomes and are transmissible to progeny in a regular manner.

Our analysis of the steady-state level of the coleopteran cryIIIB mRNA in the transgenic eggplants failed to reveal the expected molecular weight mRNA by the Northern blot procedure. Instead of a $2-\mathrm{Kb}$ band, a smaller sized band (about $1.2 \mathrm{~Kb}$ ) was observed for four of the seven tested transgenic genotypes. In most past studies of this kind (Barton et al., 1987; Vaeck et al., 1987), the presence of mRNA of expected molecular weight has been detected, although truncated mRNAs of lower molecular weight seen as a smear have been the most abundant form of lepidopteran cryI mRNA. It appears that some of the intact cryIIIB mRNA may be present in our transgenic materials in amounts below the level of detection by Northern analysis. The signal detection of the $3^{\prime}$ cryIIIB mRNA by our RNase protection assay strongly supports such an assertion. Thus, the expression of the coleopteran cryIIIB gene at the mRNA level seems to mirror the expression of the lepidopteran-type cryI gene. This is in spite of the fact that the toxin-coding region of the coleopteran cryIIIB gene shares only about 50\% sequence homology to the lepidopteran cryI genes (Hofte and Whiteley, 1989).

The origin of truncated cry mRNA in transgenic plants, although a very common occurrence, is poorly understood. Murray et al. (1991) carried out a thorough study of the kinetics of transcription of the lepidopteran genes in electroporated carrot protoplasts and-in transgenic tobacco and determined that truncated species are the result of mRNA instability. They suggested that degradation of $5^{\prime} \rightarrow 3^{\prime}$ or $3^{\prime}->5^{\prime}$ mRNA by exonuclease activity may lead to short transcripts observed on the Northern blots. Furthermore, among the various 3' end cryI deletions they tested, the highest accumulation of cryI transcript was observed with the longest segment, i.e., a construct containing 579 nucleotides of the 5 ' portion of the gene. Results of our RNase protection assay are consistent with their finding that the transcript of the 5' portion of the gene is most abundant in crytransgenic plants; in our case, there is perhaps a 15 - to 20 -fold difference in the amount of mRNA between the distal portions of 5' and $3^{\prime}$ of the coding region. This pattern of appearance of transcriptional signals could be explained by postulating that 3 ' exonuclease activity is considerably higher than $5^{\prime}$ exonuclease activity in degradation of the mRNA. Alternatively, the 5 ' distal transcripts could be the result of premature transcription termination at either a specific site or various sites, and the 3 ' transcripts are the consequence of an occasional fulllength transcription of the entire coding region. The use of a cascade of riboprobes in RNase protection assays may reveal the problems associated with cry mRNA transcription and stability. It appears then, that great similarities exist in the expression of lepidopteran and coleopteran cry genes at the mRNA level in transgenic plants. However, a difference between these two groups of genes emerged in biotoxicity tests. Most of the feeding experiments using transgenic material containing the lepidopteran cryI gene detected toxicity to a variety of lepidopteran insects, in particular, to Munduca sexta (Adang et al., 1985; Barton et al., 1987; Cheng et al., 1992). In contrast, we have failed to observe any crippling effect on $\mathrm{CPB}$ with transgenic material containing the Coleopteran $c r y I I I B$ gene. This discrepancy probably is due to the sensitivity of various insects to the toxic protein in the plants (Donovan, personal communication). However, lower concentrations of toxic protein in the leaf tissue cannot be ruled out.

Recent studies suggest that expression of cry genes at the protein level is greatly enhanced by using a synthetic gene, with altered nucleotides at the third positions of the codons, and possessing other characteristics of eucaryotic genes (Adang et al., 1993; Sutton et al., 1992). Presently, we are pursuing eggplant transformation studies with a synthetic cryIIIA gene.

\section{Literature Cited}

Adang, M.J., E. Firoozabady, J. Klein, D. DeBoer, V. Sekar, J. D. Kemp, E. Murray, T. A. Rocheleau, K. Rashka, G. Staffeld, C. Stock, D. Sutton, and D. J. Merlo. 1985. Expression of a Bacillus thuringiensis insecticidal crystal protein gene in tobacco plants, p. 345-353. In: C.J. Arntzen and C. Ryan (eds). Molecular strategies for crop protection. Alan R. Liss, New York.

Adang, M.J., M.S. Brody, G. Cardineau, N. Eagan, R.T. Roush, C.K. Shewmaker, A. Jones, J.V. Oakes, and K.E. McBride. 1993. The reconstruction and expression of a Bacillus thuringiensis cryIIIA gene in protoplasts and potato plants. Plant Mol. Biol. 21: 1131-1145.

Aronson, AL, W. Beckman, and P. Dunn. 1986. Bacillus thuringiensis and related insect pathogens. Microbial. Rev. 50: 1-24.

Barton, K.A., H.R. Whiteley, and N.S. Yang. 1987. Bacillus thuringiensis s-endotoxin expressed in transgenic Nicotiana tabacun provides resistance to Lepidopteran insects. Plant Physiol. 85: 1103-1 109.

Boulter, D., J.A. Gatehouse, A.M.R. Gatehouse, and V.A. Hilder. 1990. Genetic engineering of plants for insect resistance. Endeavor 14:185190.

Brunke, K.J. and R.L. Meeusen. 1991. Insect control with genetically engineered crops. Trends Biotechnol. 9:197-200.

Budar, F., L. Thia-Toong, M. VanMontagu, and J.P. Hernalsteens. 1986. Agrobacterium-mediated gene transfer results mainly in transgenic plants transmitting T-DNA as a single mendelian factor. Genetics 114:303-313.

Carozzi, N.B., G.W. Warren, N. Desai, S.M. Jayne, R. Lotstein, D.A. Rice, S. Evola, and M.G. Koziel. 1992. Expression of a chimeric CaMV $35 S$ Bucillus thuringiensis insecticidal protein gene in transgenic tobacco. Plant Mol. Biol. 20:539-548.

Cheng, J., M.G. Bolyard, R.C. Saxena RC, and M.B Sticklen. 1992. Production of insect resistant potato by genetic transformation with a delta endotoxin gene from Bacillus thuringiensis var. kurstaki. Plant Sci. 81:83-91.

Deroles, S.L. and R.C. Gardner. 1988a. Expression and inheritance of kanamycin resistance in a large number of transgenic petunias generated by Agrobacterium-mediated transformation. Plant Mol. Biol. 11:355364.

Deroles, S.C. and R.C. Gardner. 1988b. Analysis of the T-DNA structure in a large number of transgenic petunias generated by Agrobacteriummediated transformation. Plant Mol. Biol. 11:365-377.

DeVries, S., H. Hoge, and T. Bisseling. 1988. Isolation of total and polysomal RNA from plant tissues, p. B6:1-13. In: S. Gelvin and R. Schilperoort (eds.). Plant molecular biology manual.

Donovan, W.P., J.M. Gonzalez, M.P. Gilbert, and C. Dankocsik C. 1988. 
Isolation and characterization of EG2158, a new strain of Bacillus thuringiensis toxic to coleopteran larvae, and nucleotide sequence of the toxin gene. Mol. Gen. Genet. 214:365-372.

Donovan, W.P., M.J. Rupar, A.C. Slaney, T. Malvar, C. Gawron-Burke, and T. Johnson. 1992. Characterization of two genes encoding Bacillus thuringiensis insecticidal crystal proteins toxic to coleoptera species. Appl. Environ. Microbial. 58:3921-3927.

Dulmage, H.T. 1980. Insecticidal activity of isolates of Bacillus thuringiensis and their potential for pest control. In: H.D. Burges (ed.). Microbial control of pest and plant diseases 1970-1980. Academic Press, London. p. 193-222.

English, L. and S. Slatin. 1992. Mode of action of delta-endotoxins from Bacillus thuringiensis: a comparison with other bacterial toxins. Insect Biochem. Mol. Biol. 22:1-7.

Feitelson, J.S., J. Payne, and L. Kim. 1992. Bacillus thuringiensis: insects and beyond. Bio/Technology 10:271-275.

Fischhoff, D.A., K.S. Bowdish, F.J. Perlak, P.J.Marrone, S.M. McCormick, J.G. Niedermeyer, D.A. Dean, K.K. Kusano-Kretzmer, E.J. Mayer, D.E. Rochester, S.G. Rogers, and R.T. Fraley. 1987. Insect tolerant transgenic tomato plants. Bio/Technology 5:807-813.

Gallie, D.R., D.E. Sleat, J.W. Watts, P.C. Turner, and M.A. Wilson. 1987. The S-leader sequence of tobaccomosaic virus RNA enhances the expression of foreign gene transcripts in vitro and in vivo. Nucleic Acids Res. 15:3257-3273.

Gynheung, A., P.R. Ebert, A. Mitra, and S.B. Ha. 1988. Binary vectors. In: S. Gelvin and R. Schilperoort (eds.). Plant molecular biology manual. Kluwer, Belgium. p. A3/7.

Heberle-Bors, E., B. Charvat, D. Thompson, J.P. Schernthaner, A. Barta, A.J.M. Matzke, and M.A. Matzke. 1988. Genetic analysis of T-DNA insertions into the tobacco genome. Plant Cell Rpt. 7:571-574.

Hernstadt,C.,T.E.Gilroy,I.A. Sobieski,B.D. Bennett, and D.H. Gaertner. 1987. Nucleotide sequence and deduced amino amid sequence of a coleopteran-active delta endotoxin from Bacillus thuringiensis. Subsp. San Diego. Gene 57:37-46.

Hofte, H. and W.R. Whiteley. 1989. Insecticidal crystal proteins of Bacillus thuringiensis. Microbial. Rev. 53:242-255.

Jefferson, R.A. 1987. Assaying chimeric genes in plants: The GUS gene fusion system. Plant Mol. Biol. Rpt. 5:387-405.

Jones, J.D.G., D.E. Gilbert, K.L. Grady, and R.A. Jorgensen. 1987. TDNA structure and gene expression in petunia plants transformed by Agrobacterium tumefaciens C58 derivatives. Mol. Gen. Genet. 207:478485 .

Jorgensen, R., C. Snyder, and J.D.G. Jones. 1987. T-DNA is organized predominately in inverted repeat structures in plants transformed with Agrobacterium tumefaciens C58 derivatives. Mol. Gen. Genet. 207:471477.

Junghans, H. and M. Metzlaff. 1990. A simple method for the preparation of total plant DNA. BioTechiques 8:176.

Kingston, R.E. 1989. Preparation of poly (A)+ RNA, p. 4.5.1-4.5.2. In: F.M. Ausubel, R. Brenj, R.E. Kingston, D.D. Moore, J.G. Seidman, J. A. Smith, and K. Struhl (eds.). Current protocols in molecular biology.
Wiley, New York.

Koziel, M.G., G.L. Beland, C. Bowman, N.B. Carozzi, R. Crenshaw, L. Crossland, J. Dawson, N. Desai, M. Hill, S. Kadwell, K. Launis, K. Lewis, D. Maddox, K. McPherson, M.R. Meghji, E. Merlin, R. Rhodes, G.W. Warren, M. Wright, and S.V. Evola. 1993. Field performance of elite transgenic maize plants expressing an insecticidal protein derived from Bacillus thuringiensis. Bio/Technology 11:194-200.

Lambert, B., V. Theunis, R. Agud, K. Van Audenhove, C. Decock, S. Jansesn, J. Seuvinck, and M. Peferoen. 1992. Nucleotide sequence of gene cryIIID encoding a novel coleopteran-active crystal protein from strain BtI 109p of Bacillus thuringiensis Subsp. Kurstaki. Gene 110: 131132.

Maniatis, T., E.F. Fritsch, and J. Sambrook. 1989. Molecular cloning: A laboratory manual. 2nd ed. Cold Spring Harbor Laboratory Press.

McCown, H.B., D.E. McCabe, D.R. Russell, D.J. Robinson, K.A. Barton, and K.F. Raffa. 1991. Stable transformation of Populus and incorporation of pest resistance by electric discharge particle acceleration. Plant Cell Rpt. 9:590-594.

McGaughey, W.H. and M.E. Whalon. 1992. Managing insect resistance to Bacillus thuringiensis toxins. Science 258:1451-1455.

Murashige, T. and F. Skoog. 1962. A revised medium for rapid growth and bioassays with tobacco tissue cultures. Physiol. Plant 15:473-497.

Murray, E.E., T. Rocheleau, M. Eberle, C. Stock, V. Sekar, and M. Adang. 1991. Analysis of unstable RNA- transcripts of insecticidal crystal protein genes of Bacillus thuringiensis in transgenic plants and electroporated protoplasts. Plant Mol. Biol. 16:1035-1050.

Peferoen, M., B. Lambert, and H. Joos. 1990. New strains of Bacillus thuringiensis. Eur. Pat. Publ. no. 382990.

Perlak, F.J., R.W. Deaton, T.A. Armstrong, R.L. Fuchs, S.R. Sims, J.T. Greenplate, and D.A. Fischhoff. 1990. Insect resistant cotton plants. Bio/Technology 8:939-943.

Perlak, F.J., R.L. Fuchs, D.A. Dean, S.L. McPherson, and D.A. Fischhoff. 1991. Modification of the coding sequence enhances plant expression of insect control protein genes. Proc. Natl. Acad. Sci. USA 88:3324-3328.

Selden, R.F. 1989. Analysis of RNA by northern hybridization, p. 4.9.11.9.8. In: F.N. Ausubel, R. Brent, R.E. Kingston, D.D. Moore, J.G. Seidman, J.A. Smith, and K. Struhl (eds.). Current protocols in molecular biology. Wiley, New York.

Serres, R., E. Stang, D. McCabe, D. Russell, D. Mahr, and B. McCown. 1992. Gene transfer using electric discharge particle bombardment and recovery of transformed cranberry plants. J. Amer. Soc. Hort. Sci. 117:174-180.

Sick, A., R. Gaertner, and A. Wong. 1989. Nucleotide sequence of a Coleopteran-active toxin gene from a new isolate of Bacillus thuringiensis subsp. tolworthi. Nucleic Acids Res. 18:1305.

Sutton, D.W., P.K. Havstad, and J.D. Kemp. 1992. Synthetic cryIIIA gene from Bacillus thuringiensis improved for high expression in plants. Transgenic Res. 1:228-236.

Vaeck, M., A. Reynaerts, H. Hofte, S. Jansens, M. DeBeuckeleer, C. Dean, M. Zabeau, M. Van Montagu M, and J. Leemans. 1987. Transgenic plants protected from insect attack. Nature 328:33-37. 